\title{
MAGPANSAK IN THE CITY: THE DANCE OF THE SAMA BANGINGI IN SAN ANDRES MANILA
}

\author{
Joelle Florence Patrice Jacinto \\ University of the Philippines \\ (joelle.jacinto@gmail.com) \\ DOI: https://doi.org/10.22452/brj.sp2019no1.8
}

\begin{abstract}
Radzmina Tanjili is a Sama Bangingi woman living in San Andres, Manila since she relocated from Zamboanga in 1991. The Sama are one group of ten Islamised peoples in Southern Philippines; they were originally found all over Tawi Tawi and on several islands of the Sulu archipelago. Several miles and islands away, towards the northern part of the country, San Andres had become a settlement of Muslim migrants in the capital city of the Philippines. This research followed Radzmina around on a day when she had planned to dance - at a wedding in the community and in a rehearsal for a stage performance with a group of ladies from the same community. She shares that the Sama Bangingi word for dance is pansak, and that magpansak, or dancing, is a social activity of the community, and requires interaction with musicians, the hosts of the social event, and an audience. She also shares that dancing is a skill that everyone in the community are able to do - all know how to dance, and all do dance, even at least once in their lives, during their wedding. The Sama living in San Andres continue this tradition of dancing as being essential to their community life, even while living in a new environment, such as in the city of Manila. This paper looks at the pansak, and the changes in tradition as it is transferred from Bangingi to San Andres, Manila, as well as when mounted for stage performance.
\end{abstract}

Keywords: traditional dance, Philippine traditional dance, Sama dance and culture

\section{Introduction}

On October 17, 2017, there was a performance at the Luneta grandstand, where several indigenous groups were invited to perform their traditional dances. To represent the Sama and Tausug peoples who currently reside in San Andres, Manila, the organisers invited Nadine Galang, who performs regularly with three other women, to do their traditional dance. "Pero kailangan sabay sabay kayo (But the dancers have to perform the movements together)", Nadine recalls the specific request, which translates to there being a condition for the performance - that they have to dance together, that they 
must all do the same movements at the same time. "Sa ibang salita (in other words), choreography" (personal communication with Nadine Galang, October 15, 2017).

This implies that there is no choreography in their traditional dance and that these women only structure their dance accordingly for performances of this nature. Usually, their dance is performed at weddings and celebrations of Islamic holidays where they gather socially, such as Hari Raya Id Il Fitri and Id Il Adha (personal communication with Radzmina Tanjili, October 15, 2017).

As a dance group that performs "sabay sabay" (all together), they decided to call themselves Bulawan, or Golden, Ladies. They have only been dancing together for a year, after joining and winning a dance contest in the community.

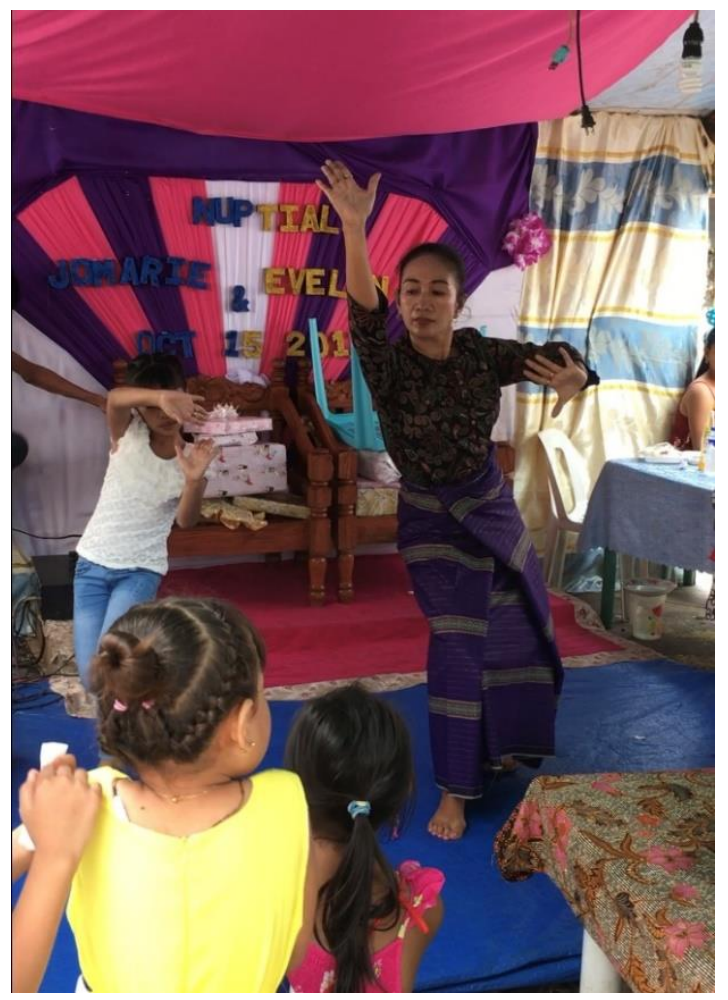

Figure 1: Radzmina Puhagan Tanjili

(Source: J. Jacinto, 2017.)

Radzmina Puhagan Tanjili was asked to join the group for this October 17 performance, to replace a member who will not be able to dance. It is her first time to join them; she usually turns down invitations to perform with a group, especially if they are dancing "sabay sabay". She does not say that she finds it difficult to dance with a group, only that she does not prefer it. She acknowledges that living in the city 
requires this kind of performance and, as with other aspects of their lives, she adjusts accordingly (personal communication with Radzmina Tanjili, October 15, 2017).

Radzmina is a Sama Bangingi woman living in San Andres since she relocated from Zamboanga in 1991. This research follows Radzmina around on a day where she has planned to dance - at a wedding in the community, and in rehearsal for the October 17 performance. She shares that their word for dance is pansak and that magpansak, or dancing, is a social activity of the community, and requires interaction with musicians, the hosts of the social event, and an audience. They also see it as a skill that everyone in the community is able to do - all know how to dance, and all do dance, even at least once in their lives, during their wedding.

This paper looks at the pansak, as well as the changes in tradition as it is transferred from Bangingi to San Andres, as well as when mounted for stage performance.

\section{The Sama Bangingi in San Andres}

The Sama is one group of around ten Islamised peoples in the southern Philippines; they were originally found all over Tawi Tawi and neighbouring islands in the Sulu archipelago (Warren, 1981, p. xxii; Casiño, 1976, pp. 9-10). They are identified according to the island they lived on, which is why the Sama Bangingi is known as such, having come from Bangingi/Balangingi Island. Most ethnographies that date back to the 1960s-1980s refer to the Sama peoples as the Samals; this is a common mistake as most of these ethnographies have Tausug as their main informants. The Tausug refer to them as Samal, while the people identify themselves as Sama. Later scholarship has acknowledged this mislabeling, as in the case of H. Arlo Nimmo (2001), who discusses his reference to the Sama Dilaut in his previous writings according to how others refer to them, correcting himself according to how the Sama Dilaut refer to themselves.

The Sama are generally shore dwellers, except for the Sama Dilaut, who are boat dwellers. Also more popularly known as Badjao/Bajau, because they were identified with a boat-dwelling people from Indonesia, the Sama Dilaut are sometimes seen as a separate ethnolinguistic group. The Sama Bangingi who are my informants and their relatives refer to the Sama Dilaut as Badjao, perhaps because they are speaking to an outsider and they know that outsiders know of the Badjao by this name. Abraham Tanjili, Radzmina's husband, shares that most of the Badjao feel out of sorts in the city because they are so used to living on the water, that they feel dizzy, similar to being seasick, now that they live on land (personal communication with Abraham Tanjili, October 15, 2017).

Both groups are known to be expert sea voyagers and have made their living as fishermen, divers, boat makers and raiders. The Sama Bangingi in particular, along with the Iranun, another Muslim ethnolinguistic group, were known as assistant 
raiders in the slave trade of the Tausug. The island of Bangingi/Balangingi was a prime location for the organisation of slave-retailing for the Sulu Sultanate for the first half of the nineteenth century (Warren, 1981, p. xxii).

According to Abraham, his grandfather, father and uncles used to drive vintas on Manila Bay to welcome tourists and foreign delegates who were guests of Imelda Marcos. Even after the Marcoses left the country, the vintas, boats with colourful sails native to the Muslim peoples, were still used as tourist attractions. He says that the reason why his relatives moved to San Andres was because it was near the coastal waters and Sama Bangingi traditionally lives near the sea.

Both Abraham and Radzmina were born in Zamboanga. Abraham moved to San Andres in the 1970s while Radzmina moved to San Andres in 1991, at the age of 19. Abraham's parents are both Sama Bangingi. Radzmina's father is Tausug, and her mother is Sama Bangingi, but they lived in a Sama Bangingi community both in Zamboanga and in San Andres, Manila. Abraham shares that San Andres was initially composed mostly of Sama Bangingi and Sama Dilaut, but is now a mix of peoples there are also some Tausug, Yakan and Maranao who live there, as well as Christians. Like Radzmina, the Bulawan ladies are half Tausug and half Sama, although Nadine and Perusa, who are sisters, were raised more as Tausug than as Sama. Perusa married a Sama Dilaut and regularly volunteers with Radzmina at the non-government office (NGO) that deals with Sama and Sama Dilaut community concerns.

Radzmina and Abraham have four children, two of which have joined the workforce - their eldest daughter Nurfaida works as a cashier in a fast food restaurant while their eldest son Alvid is employed at one of the nearby hotels. Their younger siblings are still studying. Since the two older siblings are working, Abraham and Radzmina have gone into semi-retirement: they sell instant Malaysian curry noodles in a makeshift eatery outside their home on the weekends and loan out their cellphone for their neighbours' use. The parents are proud to say that all their children can dance, and share that their third child, Mark, is interested in pursuing a career in the arts and that he is the one who is the most interested in dancing. Their youngest, Grace, is shy and does not like to dance in public, while Nurfaida and Alvid are more focused on their careers and do not dance anymore. Grace was the only Tanjili offspring who attended the wedding with us, and disappeared when her mother was called on to dance, perhaps as an excuse for not joining her in the dancing space. Abraham also did not attend the wedding, and although he says he used to dance a lot at social occasions when he was younger, he feels too old and uncoordinated to continue dancing now.

There is no concept of dance as a career for Radzmina, although her family seems to understand and acknowledge that dancing is something that she does exceptionally well, compared to others. This understanding is only fairly recent, and only because Radzmina had started dancing on stage, as a theatrical performance, as opposed to the social context that is their normal dancing practice. 


\section{Pansak, Pangalay and Igal}

Radzmina calls their dance pansak. It is not $a$ dance, but rather dance itself, the Sinama word for dance. Radzmina says that the Tausug word for dance is pangalay and the Badjao (Sama Dilaut) word for dance is igal, but they are all the same dance. She later acknowledges that there are details that are different between the three dances, which I shall later elaborate on.

This assignment of terms is a generalisation, as not all Sama translate dance as pansak. In conversations with some Sama people that I have encountered at various conferences, only some specific Sama use the word pansak, such as the Sama of Siasi, the Samalan group of islands, and apparently Bangingi Island (personal communication with Omarjan Ibrahim Jahuran, January 13, 2019), while other Sama use the word igal. As an informant, Radzmina was chosen based on her experience as a dancer in her community, not as a formal, learned expert on the different forms of the pamansak. She is merely communicating the terms she knows and uses on a regular basis. Further research is needed to organise which Sinama peoples use the word pansak, and which use the word igal, and where the etymology began and developed, as much as further research is needed to analyze how these dances are similar and different from each other, apart from the terms used to refer to them.

As a dance form, the pangalay has become popular on a national scale due to the research of Ligaya Amilbangsa, who published a book on the dance in 1983. Similar to much of the ethnographies of the Muslim Filipinos, Amilbangsa's research takes the Tausug point of view - she is married to a Tausug and lived extensively in a Tausug community. It is understandable that she would have extensive information on the pangalay, as she had first seen the dance at a Tausug wedding, and many of her initial informants were Tausug. Unfortunately, she is also introduced to the other peoples of Sulu as the Tausug see them, and if the Tausug say that the Sama all dance the pangalay as they do, then it is what is written, in the same way, that many ethnographers previously referred to the group as Samal.

According to several ethnographies, the Tausug consider themselves superior to the Sama and the Sama Dilaut, especially to the latter, primarily because it was assumed that the Sama Dilaut had not completely converted to Islam and lived as animists, especially during the times that they were sea gypsies and lived on houseboats. Richard Stone shares from fieldwork comparing the Tausug, Samal (Sama), and Badjaw (Sama Dilaut) that the groups prefer not to practice social interaction with each other, with the Tausug unwilling to befriend the Sama because "they are different... and one could not deal on a friendship basis with people one could not understand". More specifically, the Tausug feel like the Sama cannot be depended on to "fight for them". The feeling is mutual, as it turns out because of how the Sama mistrust the Tausug for being too irrational, troublesome and "hot-blooded". 
The Sama are willing to befriend the Sama Dilaut, but the latter prefer to keep to themselves (Stone, 1974, pp. 85-86).

Perhaps from Ligaya Amilbangsa's observations, the dances of the Sama and the Sama Dilaut appear the same as the dances she has seen in Sulu and Tawi Tawi, and so she has categorised them under the dance form pangalay. In her book, Pangalay: Traditional Dances and Related Folk Artistic Expressions (1983) and the entry on "pangalay" in the CCP [Cultural Centre of the Philippines] Encyclopedia of Philippine Art, Dance, 5 (1994), Amilbangsa states: "Among the Tausug and Samal, the pangalay is usually any kind of dance, regardless of function or form". She then discusses different other dances performed by the Tausug, the Samal, the Samal-Tausug, the Samal-Badjao and the Jama Mapun under this entry of pangalay, implying that these dances are either further categories of pangalay or its variants. She does not explain why these dances are grouped, although she says that they are similar dances (Amilbangsa, 1994, pp. 95-96). In her book, she names the pangalay, the langka and the lunsay as three different dance styles, and the rest of the dances are classified under these styles according to function (Amilbangsa, 1983, pp. 13-16, 27). She mentions the pamansak as a dance of the Sama in Simunul, Tawi Tawi, as danced on two bamboo poles carried on the shoulders of two men, and is also called igal ha taas patung (Amilbangsa, 1994, p. 95). Radzmina mentions seeing this dance as a dance of the Tausug and does not seem to associate the dance with her pansak.

Pamansak is also mentioned in the early research of Francisca Reyes-Aquino, where it is described as a dance found in Siasi, with the pangalay and the igal as its variants in Jolo and Sitangkai, respectively (Aquino, 1966, cited in Santamaria, 2012, p. 122). It was when Amilbangsa began to publicise her research that Aquino revised her texts to refer to the pangalay as the main dance form, and not simply a variant of pamansak.

Recent research by MCM Santamaria has clarified that the Sama Dilaut do not dance the pangalay; they call their dance form igal, and to dance is "magigal". H. Arlo Nimmo describes the angigal from his fieldwork with the Sama Dilaut of Tawi Tawi, in his Magosaha: An Ethnography of the Tawi-Tawi Sama Dilaut (2001). He was able to note that dancing was reserved for special occasions and performed in different contexts: as entertainment for weddings and other celebrations, at ceremonies, and for healing during spirit possession.

In a casual conversation with a couple of Sama Badjao in Semporna during the 2018 Regatta Lepa, an annual festival where the natives of Semporna, Sabah, decorate their lepas or large houseboats and parade them down the main river, I asked them if they danced the pangalay. They shook their head in response and said, "Igal. Pangalay is Suluk", referring to the Malaysian term for the Tausug. In Semporna, where an international igal competition is held to accompany the Regatta Lepa festival, they have specified the igal as a form with its own separate identity from the pangalay, and not just differences in language. 
The International Igal Festival that is held annually in Semporna is attended by many dance groups from all over Sabah and from some groups from Sulu and Tawi Tawi. They choreograph igal routines that contain specific stylised igal steps, such as "igal limbangan", "tariray", which uses wooden castanet-like clappers, and "igal tabawan", which is the style of igal found in Tabawan island in the Philippines, where the stepping motions of the male dancers are rather agitated because they are stepping on the watery beaches of their island as they dance (personal communication with Jahuran, April 19, 2018). The participants have become experts in these stylised forms enough to even perform dance battles, which was a new feature in the 2018 competition.

Radzmina's statement that the dances of the Tausug, Sama Dilaut and Sama Bangingi are the same is perhaps from the understanding that they all perform these dances for the same purpose: as entertainment at a wedding or other communal celebration. She is also the first to point out differences in the dances, acknowledging that the other ethnolinguistic groups have different practices, behaviours or preferences. But, the differences are not quite apparent to the untrained eye, in the same way, that one cannot distinguish between Tausug, Sama Bangingi, Sama Dilaut and even Christian among the guests attending a Sama wedding on October 15, 2017.

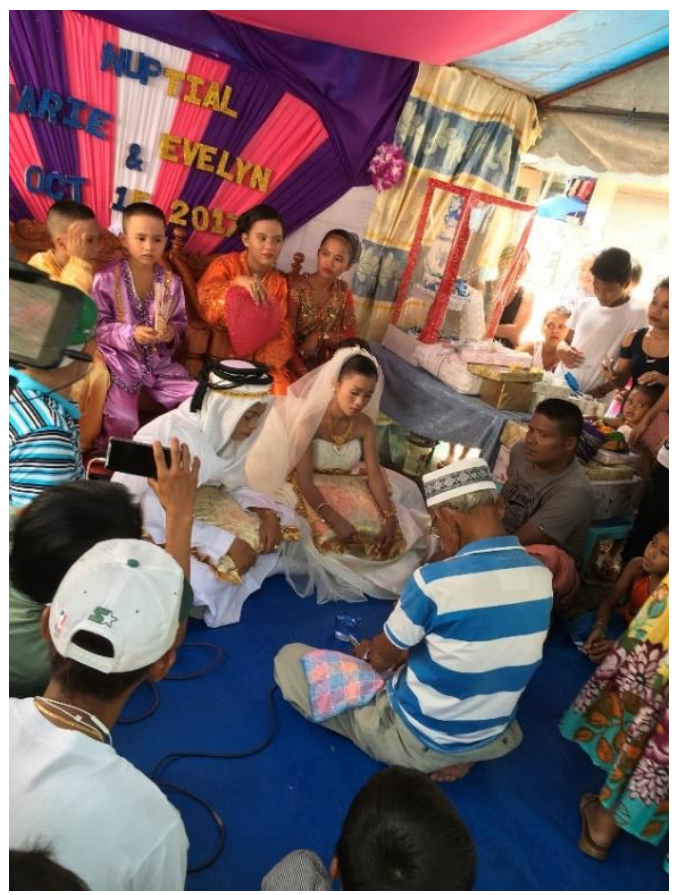

Figure 2: The wedding ceremony of Jomarie and Evelyn.

(Source: J. Jacinto, 2017.) 


\section{The wedding dance}

The wedding of Jomarie, a Sama Dilaut boy, and Evelyn, a Sama Bangingi girl, was held in what they considered their town plaza, or a centre courtyard in the middle of the community, with two tents set up for the ceremony. The wedding guests, who are members of the community as well as visitors from other cities, are offered a meal when they arrive: they sit under the tent and eat packed lunches of rice, chicken, fish and vegetables. As soon as they finish eating, they vacate their table for other arriving guests, and sit around the tent or in shady areas around the plaza, where plastic chairs are placed, to chit chat while waiting for the bride and groom. All the while, under the tent, music from an electronic organ plays nonstop to accompany dancers.

The dancers are called up to perform by one of the musicians, usually whoever is holding the microphone for announcements and singing. The Barangay of San Andres is small enough for everyone to know each other, and to invite the dancers onto the stage. If there are outsider visitors, the host will inform whoever is holding the microphone to invite them to dance after they have finished eating. The dancers usually perform either as a solo, or, if they are shy, they ask a friend to join them. The dancers tell the organ player what music they wish to dance to, and the musician complies.

The dancer decides when to enter the dancing area once the music starts. It is also the dancer who decides when the dance is finished, sometimes, just abruptly getting out of position and rushing off the dance floor. When that happens, the music also abruptly stops, and if there was an accompanying singer, he announces "Okay!" as if to attempt at a proper ending to the dance. Then, they call a new dancer to perform.

It does seem that they are all performing the same dance, with different levels of technical and performative prowess. But there are subtle differences. The most obvious difference is the music that they dance to. When the dancers come up to dance, they tell the musicians what kind of song they wish to dance to the tubaylasa, the lolaybaru, or the umaral or kulintang. The first two are songs; the last one is the only one with no accompanying singer, only the playing of the kulintang, or in this case, an electronic organ simulating the playing of the kulintang.

Using an electronic keyboard organ to replace the kulintangan orchestra had become standard practice not only in this impoverished community in San Andres but also in the Sulu archipelago and Sabah. Bernard Ellorin (2012) explains that the decline of the Philippine economy impacted the production of traditional musical instruments in the Sulu archipelago, and the use of electronic keyboard, specifically the Technics KN5000, because it is able to duplicate the sound of conventional instruments (p. 63), were cheaper to use than to purchase a kulintang set or to hire an ensemble (p. 57).

The lolaybaru is said to be relatively new, "baru" translates to "new" from Bahasa Melayu, and the most popular among the guests who were called on to dance. 
It is an interactive dance where lyrics of the accompanying singer somewhat dictates the movements of the dancer. It has a very "masa" pop song sound, with masa implying lower class taste of the masses, especially because it is performed on the electronic keyboard and the melody has an intentionally jeering lilt, further hyped up by the singer.

According to Radzmina, the singer tells the dancer what he would like to see her do and she complies; if he sings for her to shake her hips, the dancer then shakes her hips vigorously. She considers the lolaybaru a fast dance, although this observation may be due to the fact that such an exchange can be exciting for both the musicians and the dancer and the music and the dancing speeds up according to the enthusiasm of the singer.

An interesting counter observation is from Abraham, who shares that the singer is praising the dancer. Both statements are possible at once: the singer praises the dancer, who is then encouraged by the praise to wave her arms wider, to shake her hips faster, to dance even longer. Ellorin (2012) describes a similar practice in the loloh or $l e^{\prime} l e^{\prime}$, obviously related to the lolay, where the singer is usually the husband of the igal dancer and sings praises to his wife (p. 61).

Radzmina usually dances to the umaral/kulintang, although sometimes dances to the lolaybaru as well, saying, "Minsan, gusto ko rin kumembot." ("Sometimes, I also wish to sway my hips.") An interesting related observation of dancing to the lolay is recounted by Desiree Quintero, of the Suluk (Tausug in Sabah, Malaysia) performing a choreographed pangalay routine to two different songs. The original dance choreographed to "Lolay Liyangkit" included a natural swaying of the hips with each bounce and step. However, the music was changed to "Tiyula Itum", which had more sustained motif development in the music and was less upbeat than the lolay. As a result, the swaying movements in the dance routine disappeared (Quintero, 2017, pp. 126-128). Although the different ethnolinguistic groups call the dance by different names, the quality of the dancing similarly changes with the music that is danced to.

In contrast, the focus of the pansak danced to the kulintang focuses more on the arms and hands. The concentration on the details of the hand movements is so intense that when bills of money are inserted in between Radzmina's fingers, she frees her fingers by loosening the grip on the bills and letting them fall on the floor.

This tradition of inserting money in between the dancers' fingers is called panji. It is at once payment for the performance, as well as encouragement for the children to want to learn to dance. As mentioned earlier, all in the community should know how to dance and must dance at their wedding. One of the reasons that this is mandatory is so that the wedding guests can give money to the bride and groom as they dance. At Jomarie and Evelyn's wedding, Jomarie was the only male who danced. He was very stiff and invariable, but this did not matter as many wedding guests approached him at once, almost mobbing him, to insert the money in between his fingers and embracing and kissing him in congratulations. 
The dancing is interrupted only by the appearance of the bride and groom. According to the conversations that Radzmina's family had with the mother of the groom, it seems that the wedding ceremony is usually performed at another location and the couple should only arrive after they are formally wed. On this day, however, the ceremony is performed under the tent, in front of all their visitors. This ceremony took place in the early afternoon after the imam has finished with the day's prayers at the local masjid or mosque.

After the ceremony, several special guests are called to dance in front of the couple. These may be their close friends or relatives; they are also usually very short in duration, compared to the dancers who were called before the arrival of the bride and groom, as they perform for only one or two minutes and leave the dance floor immediately.

After all the special guests have danced, the bride stands up and dances, while her entourage and other guardians strategically hold up her veil and the massive train on her Western white wedding gown. The groom, also wearing white, and in an Arabic turban, dances after the attention on the bride has subsided. The young members of their entourage are then called on to dance, after which, the bride and groom are called up again to perform a "sweet" - an American-influenced slow dance where the couple are allowed to touch each other. While it is generally during the slow dance in Filipino Christian weddings that guests pin bills of cash on the clothes of the newlyweds, there is none of that at this wedding, as the guests had already given their panji during their dances. The slow dance is a Western/non-Muslim practice that these Muslims have adopted for fun. Then, various guests dancing the pansak continue well into the evening.

\section{Learning the dance - imitation and interaction}

Outside the ceremonial tent, children run around, playing games, eating wedding pastries and cola, and dancing with each other to the music blaring from loudspeakers. This is how the Sama learn how to dance, they watch the older dancers, and try out the moves on their own. Many informal contests are organised during festive occasions to encourage the children to dance. When children see the adults placing money between the fingers of the children who participate in these contests, they decide to join in the dancing. Those children who become serious and passionate about dancing usually join their elder relative when she is called to dance; this is how many skilled Sama dancers practice and perfect their craft. The elders who see this interest then take them on as a sort of prodigy, advising them of how to dance better, what is the correct posture and carriage of their arms, and so on.

This was how Radzmina learned to dance. Her aunt was always called on to dance at weddings, and Radzmina would copy her. She became Radzmina's mentor, and always brought her when attending weddings, even in other cities and provinces. 
While Radzmina's children have either outgrown dancing or are too shy to join her, Radzmina allows two of her nieces to join her.

Her maternal grandmother also coached Radzmina on form and detail; Radzmina remembers being constantly told to focus her gaze on her arms and to emphasise the supple and extending line from her arms to fingers. Abraham says the term they use in instruction is "palantik", as in "palantikin ang kamay", or make the shape of the hand more beautiful.

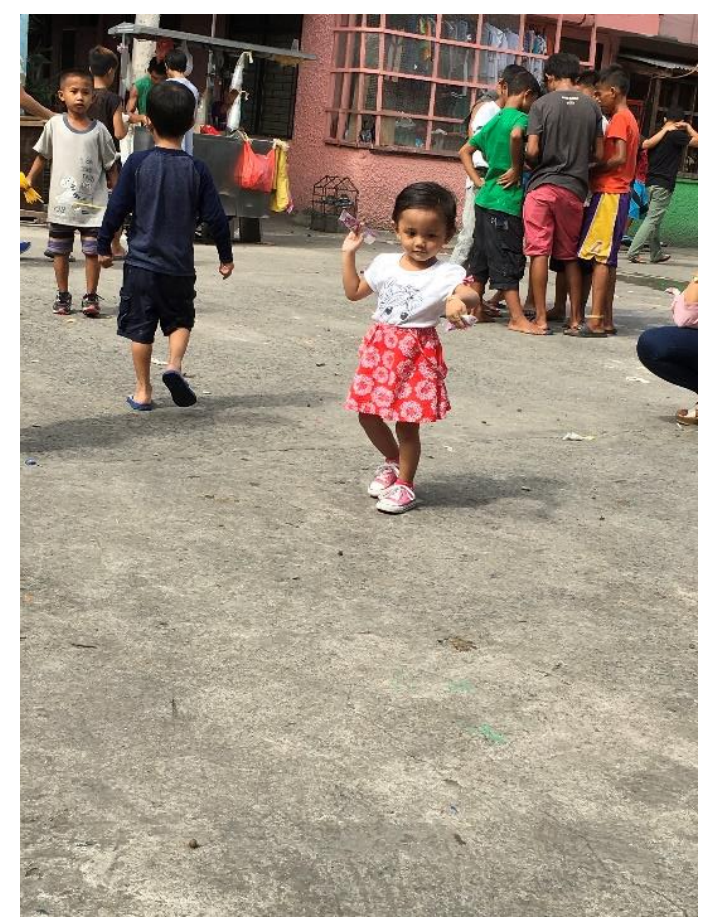

Figure 3: A young igal dancer strutting with money between her fingers (Source: J. Jacinto, 2017.)

The movement of the arms is derived from the waves of the ocean, and they describe the pulsation of the fingers as "umaalon-alon" (alon directly translates to "wave"). This movement is connected to the placement of the elbow and gives the pansak its basic aesthetic feature. The feet and legs also move according to the carriage of the arms, as an extension of the waves that ripple through the body. This also holds true for the shoulders, although the movement of the shoulders, as with the hips, is limited to emphasise the regal carriage of the arms.

Radzmina learned to dance in Zamboanga, where her grandmother and aunt would play music on an actual kulintang. Kulintang musicians are supposed to follow the movements of the dancer, so as much as the dancer is the one who dictates when 
to begin and end her dance, she also dictates how the dance unfolds. When Radzmina moved to San Andres, she found that this is not a skill possessed by musicians in the city. First of all, there are few kulintang instruments to be found outside Mindanao and even less in a community such as San Andres. Secondly, they are learning how to play the instrument without the context of performing in weddings and with dancers, which is not a privilege that city dwellers can enjoy.

Musicians, therefore, may be able to play the music on an electronic keyboard, but not to interact with a dancer during a performance. Radzmina shares that Manila musicians playing the actual kulintang know how to play the instrument but are unaware of the interaction that is supposed to happen between musician and dancer, and at performances where she is accompanied by a live kulintang ensemble, she compromises by following the music, instead of the other way around. At Pesta Igal 2016, which was also attended by groups from Mindanao and Sabah, Radzmina had the chance during rehearsal to try dancing with musicians from Tawi-Tawi and was delighted that they knew how to follow the dancer's movements instead of the other way around.

\section{Dance as performance, staging the pansak}

In April 2012, Radzmina joined an event for indigenous peoples in Angeles, Pampanga, organised by an NGO for the Sama Dilaut and the Department of Social Welfare and Development (DSWD). When she signed up to be a sweeper, she saw a list for dancers. Since she knew that she could dance, she listed her name there as well. This was her first stage performance, in a dance-drama about the Sama Dilaut/Badjao entitled Laot, Lungsod, Langit, choreographed by Ines Fojas. Since then, Radzmina has been invited to perform the pansak at events, organised by government and nongovernment organisations, and has joined MCM Santamaria's Pesta Igal at the GT Toyota Auditorium at the University of the Philippines, Diliman.

Radzmina's understanding of her dancing is that she enjoys it and will take opportunities to dance when they are offered. She also sees it as a way to introduce their kind of dancing to other cultures. Meanwhile, her husband encourages Radzmina to perform, partly because he knows she enjoys it, but also because he knows she is good at it. He shares that the first time he knew that she was a good dancer was at their wedding when the agong player started to challenge Radzmina while she did her bridal dance, and she met his challenge, to the delight of the wedding guests. He remembers hearing his father remark that Radzmina's dancing skills were very potent. Since then, when they attended weddings, he would notice how his family would always request her to dance, and at times, more than once. Radzmina shares that they usually dance

only once during a wedding to give chances to others to be called; that Abraham's relatives urge Radzmina to dance again in the same day means that they enjoy 
watching her dance. Radzmina's invitation to perform at events also reiterates their acknowledgement of Radzmina's capabilities.

It is the insistence that a group perform steps together or "sabay sabay" or memorising a set or choreographed sequence that Radzmina finds the most challenging about performing the pansak outside of its original context. To her, the guests watching her at a wedding are the same as the audiences watching her inside a hotel or a theatre that she is dancing to be looked at. "Pero mahirap talaga ang may bilang (But it's really hard when there are counts)", she opines, coming from a mostly improvisational dance tradition.

The dances of these Muslim peoples that are seen in Manila are mostly choreographed pieces, where groups dance "sabay sabay" "na may bilang". These are mostly in the concerts of the Bayanihan and other folk dance groups and in the performances of Ligaya Amilbangsa. In keeping with Amilbangsa's theory that pangalay is a prototype of dance for the peoples in the Sulu archipelago, she uses the movement vocabulary to make new dance pieces, choreographed to other types of music, such as Filipino (Christian) folk songs. MCM Santamaria, a student of Amilbangsa, has done extensive research on the igal of the Sama Dilaut and uses the igal movement vocabulary to choreograph dance theatre pieces, the most recent being Sintang Dalisay, a reimagination of Shakespeare's Romeo and Juliet set among the Sama Dilaut.

\section{Sama living in the modern world}

Nadine Galang, self-appointed leader of the Bulawan Ladies, sees this need for choreography as part of adjusting to life in the city, as part of living in the "modern world". That this is what the people in Manila expect to see, so they had to make their adjustments. She asks me if I had seen the dancing at the wedding earlier that day, and says that this is what their dance looks like, but that kind of dancing cannot be staged as a theatrical performance. In a wedding, where the dancing is improvised, Nadine offers that any kind of dancing will do. Additionally, all the dancing is the same, has the same movements. She shares that, to complete the dance, they had to choreograph steps, which makes it different from their standard practice.

I attended their rehearsal through Radzmina's request. I was told that they do not normally rehearse so much and that this rehearsal was Radzmina's idea. Radzmina explains that she needs this rehearsal because this is the first time she will be dancing with them. If they are expected to dance together, she needs to rehearse with them more to remember the sequence of the dance, the counts of the steps, and to make the dancing feel more natural.

The dance they are performing is to the third style of music, the tubaylasa. It is a popular love song that tells a story, Tubaylasa is the name of the girl being sung to. 
Later, Radzmina tells me that more Tausug dance to "Tubaylasa" because they like the song, while the Sama Dilaut prefers the lolaybaru.

The dance is mainly repetitive movement motifs performed uniformly, on both sides, on alternating counts of four, and changes when the musical phrase changes. They move around the stage only to change their group formation, rather than devising creative floor patterns as other Filipino folk dances are structured. Indeed, since pamansak and igal are not traditionally performed with elaborate floor patterns in their community, they are not aware that this can be a choreographic device that can be used. The choreographed group dance then appears very basic and hardly resembles the pamansak, igal or pangalay. Perhaps in time, if Nadine and the Bulawan Ladies pursue choreographed pamansak more seriously, they could develop their creativity and make the dance more attractive, as those who choreograph igal routines for the annual International Igal Festival in Semporna, although it seems unlikely that they will move towards this end goal in the future.

Radzmina also opines that some of the steps that Nadine and the other ladies had choreographed seem either invented or from the Tausug dance tradition. Being raised as Tausug, Nadine and Perusa follow many customs practised by the Tausug, so Radzmina is guessing that this includes dancing. One particular step that she has never seen before is where the women raise their arms over their heads with their hands flexed and alternately push their palms slightly upwards, their hips and shoulders following the motions. But this may not necessarily be a traditional Tausug dance movement, given many possibilities of influences in the city, as well as Nadine's belief that any kind of dancing is appropriate when they choreograph a set routine, because there are no specific steps that belong exclusively to the pangalay, igal or pansak, since pangalay, igal and pansak mean dance, in general.

Radzmina agrees that there are many changes in the dance tradition while compromising to life in the city and new contexts of performance. But, it is not just the city that changes the dance, it is time as well, and the people who perform it. She says that researchers like myself want to see "kamatto'han", which is the dancing of their grandmothers, or the old style of dancing, dancing that is no longer performed exactly the same by the Sama today.

She understands the need for people of other cultures to see the pansak, although not necessarily in its original iteration, but also all its different forms and contexts. She is, after all, a propagator of its current form, and is not worried about the tradition disappearing. They had been dancing pansak before other people knew what it was and will continue to dance it for generations to come. 


\section{References}

Aquino, F.R.A. (1966). Philippine Fold Dance and Songs. Manila: Burreau of Public Schools.

Amilbangsa, L. (1983). Pangalay: Traditional Dances and Related Folk Artistic Expressions. Manila: Filipinas Foundation.

Amilbangsa, L. (1994). Pangalay. In N. G. Tiongson (Ed.), CCP Encyclopedia of Philippine Art, Dance, 5 (pp. 95-96). Manila: Cultural Center of the Philippines.

Casiño, E. (1976). The Jama Mapun: A Changing Samal Society in the Southern Philippines. Quezon City: Ateneo de Manila University Press.

Ellorin, B. (2012). Contemporary Trends and Influences in Music and Dance of Sama. In Sama Celebrations: Ritual, Music and Dance of Sama Dilaut and Sama Bajau in Southern Philippines and North Borneo (pp. 117-141). Kuala Lumpur: University of Malaya.

Nimmo, H. A. (2001). Magosaha: An Ethnography of the Tawi-Tawi Sama Dilaut. Quezon City: Ateneo de Manila University Press.

Quintero, D. A. (2017). “Tiyula Itum" and Pangalay: Suluk Anthemic Expressions in Sabah, Malaysia. Borneo Research Journal, 11, 118-132.

Santamaria, MCM. (2012). Pamansak (Pangalay or Igal): On Labels, Dominant Discourses and Diversity in Philippine Dance Research. In Sama Celebrations: Ritual, Music and Dance of Sama Dilaut and Sama Bajau in Southern Philippines and North Borneo (pp. 117-141). Kuala Lumpur: University of Malaya.

Stone, R. (1974). Intergroup Relations among the Tausug, Samals and Badjaus of Sulu. In P. G. Gowing \& R. D. McAmis (Eds.), The Muslim Filipinos: Their History, Society and Contemporary Problems (pp. 74-99). Manila: Solidaridad Publishing House.

Warren, J. (1981). The Sulu Zone 1768-1898: The Dynamics of External Trade, Slavery, and Ethnicity in the Transformation of a Southeast Asian Maritime State. Quezon City: New Day Publishers. 